\title{
Sociodemographic, behavioral, and environmental factors associated with the incidence of leptospirosis in highlands of Ponorogo Regency, Province of East Java, Indonesia
}

\author{
Hari Basuki Notobroto ${ }^{a, *}$, Yudied Agung Mirasa ${ }^{b}$, Firman Suryadi Rahman ${ }^{a}$ \\ ${ }^{\text {a }}$ Faculty of Public Health, Universitas Airlangga, Surabaya, Indonesia \\ ${ }^{\mathrm{b}}$ The Environmental Health Center and Disease Control, Surabaya, Indonesia
}

\section{A R T I C L E I N F O}

\section{Keywords:}

Behavioral

Environmental

Highlands

Leptospirosis

Sociodemographic

\begin{abstract}
A B S T R A C T
Leptospirosis is a zoonotic disease that globally spreads and has the potential to become an epidemic. In Indonesia, the incidence of leptospirosis tends to increase with case fatality rate ranged from 5 to $12 \%$. Ponorogo is one regency in Province of East Java, Indonesia that has high incidence of leptospirosis. The objective of this study was to identify sociodemographic, behavioral, and environmental factors associated with incidence of leptospirosis in highlands of Ponorogo regency. The study used case control design conducted in 15 villages in the highlands of Ponorogo regency. The sample was composed of 28 cases of leptospirosis and 112 nonleptospirosis. The variables of this study were sociodemographic, behavioral factors, environmental factors, and incidence of leptospirosis. Data was collected by interview using questionnaire and observation of environmental conditions. Data was analyzed using chi square and logistic regression. The result showed that factors associated with the incidence of leptospirosis were education $(\mathrm{p}=0.019)$, occupation $(\mathrm{p}=0.003)$, health practice $(\mathrm{p}=$ 0.007), house density ( $\mathrm{p}=0.013)$, livestock ownership $(\mathrm{p}=0.004)$, distance from house to cowshed $(\mathrm{p}=0.024)$, cow ownership $(p=0.010)$, and the presence of rats in the house $(p=0.050)$. The result of logistic regression analysis showed that the variables dominantly associated with the incidence of leptospirosis were livestock ownership, education (low), house density (crowded), and distance from house to cowshed (less than $10 \mathrm{~m}$ ). In conclusion, sociodemographic, behavioral, and environmental factors were associated with the incidence of leptospirosis in highlands of Ponorogo Regency.
\end{abstract}

\section{Introduction}

Leptospirosis is a zoonotic disease that is widespread in the world, can attack humans or animals, and has the potential to become an epidemic that has a significant impact on health. ${ }^{1}$ This disease is caused by a spiral-shaped bacterial infection of the genus Leptospira pathogens that can naturally be transmitted from vertebrate animals to humans or vice versa. ${ }^{2}$ It can be transmitted through direct contact of mucous membranes or opened skin with a source of infection or through intermediary media such as water, soil and food. One of the most important reservoirs that can transmit leptospirosis are mammals including rats, cattle, dogs, and cats. ${ }^{3-5}$

The incidence of leptospirosis in the world is estimated at 320,000 per year, ${ }^{6}$ mostly in tropical and subtropical areas, both in the highlands and lowlands. ${ }^{7-9}$ The incidence of leptospirosis often occurs in areas with dense population, flooded areas, poor waste management, reservoirs and poor sanitation conditions. ${ }^{10}$ Leptospirosis cases in Indonesia tend to increase in the number of cases and deaths in the period 2004-2013. The highest incidence occurred in DKI Jakarta due to heavy flooding in 2007 with 113 cases and 20 people died (CFR $=19.4 \%)^{11}$ From 2007 to 2013 leptospirosis cases in Indonesia were always high with a CFR of $5-12 \% .{ }^{12}$ In Ponorogo Regency the number of leptospirosis cases until 2015 was 92 with 5 deaths. The highest number of cases was in 2011 with 30 cases and 4 deaths (CFR 13.3\%), 74 cases (80\%) occurred in the highlands that were not flooded areas. The distribution of leptospirosis cases in Ponorogo Regency until 2015 was spread over 10 subdistricts and there are 4 subdistricts that have height of more than $500 \mathrm{~m}^{13}$

The high cases of leptospirosis in the tropics and subtropics areas can be associated with unfavorable environmental conditions. This makes

\footnotetext{
* Corresponding author.

E-mail addresses: haribasuki.n@fkm.unair.ac.id (H.B. Notobroto), ymirasa@gmail.com (Y.A. Mirasa), firmansrahman@gmail.com (F.S. Rahman).
} 
Leptospirosis bacteria grow and reproduce. ${ }^{14}$ The wide spread of leptospirosis that attacks the community can potentially cause outbreaks. Therefore, it is important to carry out cross-sectoral outbreak control efforts in assisting health workers in conducting epidemiological investigations, coordinating the formation of fast-moving teams, empowering communities, and carrying out community control. ${ }^{15-17}$

According to the Directorate General of P2PL, Ministry of Health, RI, the type of occupation is an important risk factor for humans. ${ }^{18}$ The results of an epidemiological investigation of the Ponorogo District Health Office showed that leptospirosis cases were often found in farmers $(60.5 \%)$ both farmers in rice fields and farmers in clove and pine plantations, cattle farmers, and sand miners in rivers (17.4\%). Most cases were male with productive age between 30 and 55 years and $79 \%$ cases have cattle. ${ }^{19}$ This occupational risk factor fits within the risk groups, but there are other occupational factors for the Ponorogo area, namely sand mining in the river. ${ }^{20}$

Environmental risk factors related to the incidence of leptospirosis included housing and workplace sanitation conditions. These conditions include open sources of wastewater disposal and the presence of rats. Semipermanent houses and buildings that do not have ceilings make it easier for rats to enter the house. The presence of garbage around the house also makes the rat population around the house increase. Other environmental risk factors are history of flooding, the presence of water around the house, the waterways that are not smooth, the sanitation of the house that is not good, and high rainfall. ${ }^{21,22}$

The risk in the highlands in Ponorogo is the factors of unhealthy settlement such as semi-permanent house walls, house floors made of soil, cowshed in the house, the presence of potential disease vectors, namely the presence of rats inside and outside the house. ${ }^{23}$ These conditions indicate that the potential for the spread of leptospirosis cases is still high and requires more comprehensive control in terms of health, farming, and agriculture. ${ }^{24,25}$ In addition to individual and environmental characteristics, behavior is an important factor in the incidence of leptospirosis. Knowledge, attitudes, and individual practice in the prevention of leptospirosis play important role for the incidence of leptospirosis. The objective of this study was to analyze the influence of sociodemographic characteristics, behavior and environmental factors on the incidence of leptospirosis in the highlands of Ponorogo Regency, East Java Province.

\section{Materials and methods}

This research was analytic observational with case control design. The study was conducted in 15 villages of 4 subdistricts in the highlands of Ponorogo Regency, East Java Province, Indonesia in the period March 2016 to February 2017. Cases were populations who had suffered from leptospirosis one-year period prior to the data collection period. Data of cases were obtained from the Primary Health Cares. Controls were populations that had never suffered from leptospirosis, living in the same village with the leptospirosis cases. Sample of case were all cases of leptospirosis in 15 villages as many as 28 people. Sample of controls were neighbors of leptospirosis cases drawn by simple random technique with the ratio of case and control is $1-4$. So 112 people were taken as controls. The variables studied in this research were sociodemographic characteristics, including age, gender, education, and occupation; behavior, including knowledge about leptospirosis, attitudes, practices for preventing leptospirosis, and mobility; environmental factors, including house density, livestock ownership, distance from house to cowshed, sewerage, puddle, source of clean water, the presence of rats in the house and around the house, trash cans, vegetation, and road conditions. Data was collected by interview using questionnaire and observation of environmental conditions. Data was analyzed descriptively by tabulating the distribution of data, bivariate analysis using Chi Square test or Fisher's exact test, and multivariate analysis using multiple logistic regression.

\section{Results}

This research was conducted in 15 villages from 4 sub-districts in Ponorogo Regency, East Java Province. One hundred and forty respondents consisting of 28 cases of Leptospirosis and 112 controls were interviewed. The distribution of respondents is described as follows.

\section{Sociodemographic Characteristics}

The average age of the respondents is $45.86 \pm 9.41$ years. The mean age in the case group was $47.86 \pm 7.18$ years while in the control group is $45.36 \pm 9.86$ years. There was no significant difference in mean age between case and control groups ( $p>0.05)$. The distribution of respondents by age, sex, education, and occupation is described in Table 1 .

Table 1 shows that the age of cases ranged from 31 to 60 years, most of the them were male (60.7\%), had low education (85.7\%), and worked as farmers or breeders (82.1\%). There was no significant difference in age and gender distributions between the case and control groups ( $p>$ 0.05 ), but there were significant differences in the distribution of education and occupation between the case and control groups $(p<0.05)$. It seems that low education and employment as farmers or breeders have a relationship with the incidence of leptospirosis.

\section{2 vBehavioral Factors}

There are four behavioral aspects observed in this study, namely the respondent's knowledge about leptospirosis, attitudes, leptospirosis prevention practices, and mobility. The score of each aspect is classified into two categories, good and poor. The distribution of each behavioral aspect is described in Table 2.

In Table 2 it can be seen that the practice of leptospirosis prevention is the only aspect that has a relationship with the incidence of leptospirosis. Respondents who had poor practice had a higher probability of suffering from leptospirosis $(\mathrm{p}<0.05)$. Knowledge about leptospirosis, attitude, and mobility had no relationship with the incidence of leptospirosis $(\mathrm{p}>0.05)$.

\section{Environmental Factors}

There are 13 environmental aspects discussed in this study, namely: house density, livestock ownership, distance from house to cowshed, cow ownership, goat ownership, sewerage, puddle, source of clean water, the presence of rats in the house, the presence of rats around the house, vegetation, trash can, and road conditions. Each aspect is categorized based on the aspects presented in Table 3 .

Based on the results of the bivariate test of environmental factors with cases and controls, it is known that, environmental aspects related to the incidence of leptospirosis are: house density (0.013), livestock ownership (0.004), distance from house to cowshed (0.024), cow ownership (0.010) and the presence of rats in the house (0.050) with a value of $\mathrm{p}<0.05$.

Table 1

Distribution of respondents based on sociodemographic characteristics.

\begin{tabular}{lllll}
\hline Characteristics & Category & Case $(\mathrm{n}=28)$ & Control $(\mathrm{n}=112)$ & $\mathrm{P}$ \\
\hline Age (years) & 30 & $0(0.0 \%)$ & $7(6.3 \%)$ & 0.258 \\
& $31-40$ & $4(14.3 \%)$ & $26(23.2 \%)$ & \\
& $41-50$ & $12(42.9 \%)$ & $40(35.7 \%)$ & \\
& $51-60$ & $12(42.9 \%)$ & $34(30.4 \%)$ & \\
Gender & $>60$ & $0(0.0 \%)$ & $5(4.5 \%)$ & \\
& Male & $17(60.7 \%)$ & $60(53.6 \%)$ & 0.640 \\
Education & Female & $11(39.3 \%)$ & $52(46.4 \%)$ & \\
& Low & $24(85.7 \%)$ & $67(59.8 \%)$ & 0.019 \\
& Medium to High & $4(14.3 \%)$ & $45(40.2 \%)$ & \\
& Farmers/ & $23(82.1 \%)$ & $54(48.2 \%)$ & 0.003 \\
& breeders & & & \\
& Another & $5(17.9 \%)$ & $58(51.8 \%)$ & \\
\hline
\end{tabular}


Table 2

Distribution of respondents based on behavioral factors.

\begin{tabular}{lllll}
\hline Behavior & Category & Case $(\mathrm{n}=28)$ & Control $(\mathrm{n}=112)$ & $\mathrm{P}$ \\
\hline Knowledge & Good & $13(46.4 \%)$ & $62(55.4 \%)$ & 0.525 \\
& Poor & $15(53.6 \%)$ & $50(44.6 \%)$ & \\
Attitude & Good & $19(67.9 \%)$ & $85(75.9 \%)$ & 0.530 \\
& Poor & $9(32.1 \%)$ & $27(24.1 \%)$ & \\
Practice & Good & $13(46.4 \%)$ & $84(75.0 \%)$ & 0.007 \\
& Poor & $15(53.6 \%)$ & $28(25.0 \%)$ & 1000 \\
Mobility & Low & $25(89.3 \%)$ & $97(86.6 \%)$ & \\
& High & $3(10.7 \%)$ & $15(13.4 \%)$ & \\
\hline
\end{tabular}

Table 3

Distribution of respondents by environmental factors.

\begin{tabular}{|c|c|c|c|c|}
\hline Environment & Category & $\begin{array}{l}\text { Case }(n= \\
28)\end{array}$ & $\begin{array}{l}\text { Control (n } \\
=112)\end{array}$ & $\mathrm{P}$ \\
\hline \multirow[t]{2}{*}{ House density } & Not crowded & $\begin{array}{l}13 \\
(46.4 \%)\end{array}$ & $82(73.2 \%)$ & 0.013 \\
\hline & $\begin{array}{l}\text { Crowded } \\
(<8 \mathrm{~m} 2 / \mathrm{prs})\end{array}$ & $\begin{array}{l}15 \\
(53.6 \%)\end{array}$ & $30(26.8 \%)$ & \\
\hline \multirow[t]{2}{*}{ Livestock ownership } & No & $1(3.6 \%)$ & $37(33.0 \%)$ & 0.004 \\
\hline & Yes & $\begin{array}{l}27 \\
(96.4 \%)\end{array}$ & $75(67.0 \%)$ & \\
\hline \multirow[t]{2}{*}{$\begin{array}{l}\text { Distance from house to } \\
\text { cowshed }\end{array}$} & $10 \mathrm{~m}$ or more & $\begin{array}{l}10 \\
(35.7 \%)\end{array}$ & $69(61.6 \%)$ & 0.024 \\
\hline & Less than $10 \mathrm{~m}$ & $\begin{array}{l}18 \\
(64.3 \%)\end{array}$ & $43(38.4 \%)$ & \\
\hline \multirow[t]{2}{*}{ Cow ownership } & No & $8(28.6 \%)$ & $65(58.0 \%)$ & 0.010 \\
\hline & Yes & $\begin{array}{l}20 \\
(71.4 \%)\end{array}$ & $47(42.0 \%)$ & \\
\hline \multirow[t]{2}{*}{ Goat ownership } & No & $6(21.4 \%)$ & $39(34.8 \%)$ & 0.258 \\
\hline & Yes & $\begin{array}{l}22 \\
(78.6 \%)\end{array}$ & $73(65.2 \%)$ & \\
\hline \multirow[t]{2}{*}{ Sewerage } & Eligible & $\begin{array}{l}21 \\
(75.0 \%)\end{array}$ & $101(90.2 \%)$ & 0.053 \\
\hline & Not eligible & $7(25.0 \%)$ & $11(9.8 \%)$ & \\
\hline \multirow[t]{2}{*}{ Puddle } & No & $\begin{array}{l}11 \\
(39.3 \%)\end{array}$ & $65(58.0 \%)$ & 0.117 \\
\hline & Yes & $\begin{array}{l}17 \\
(60.7 \%)\end{array}$ & $47(42.0 \%)$ & \\
\hline \multirow[t]{3}{*}{ Source of clean water } & Boreholes & $1(3.6 \%)$ & $11(9.8 \%)$ & 0.134 \\
\hline & Dug well & $5(17.9 \%)$ & $36(32.1 \%)$ & \\
\hline & Water springs & $\begin{array}{l}22 \\
(78.6 \%)\end{array}$ & $65(58.0 \%)$ & \\
\hline \multirow{2}{*}{$\begin{array}{l}\text { The presence of rats in } \\
\text { the house }\end{array}$} & No & $2(7.1 \%)$ & $30(26.8 \%)$ & 0.050 \\
\hline & Yes & $\begin{array}{l}26 \\
(92.9 \%)\end{array}$ & $82(73.2 \%)$ & \\
\hline \multirow{2}{*}{$\begin{array}{l}\text { The presence of rats } \\
\text { around the house }\end{array}$} & No & $6(21.4 \%)$ & $30(26.8 \%)$ & 0.735 \\
\hline & Yes & $\begin{array}{l}22 \\
(78.6 \%)\end{array}$ & $82(73.2 \%)$ & \\
\hline \multirow[t]{2}{*}{ Vegetation } & No & $5(17.9 \%)$ & $31(27.7 \%)$ & 0.411 \\
\hline & Yes & $\begin{array}{l}23 \\
(82.1 \%)\end{array}$ & $81(72.3 \%)$ & \\
\hline \multirow[t]{2}{*}{ Trash can } & $\begin{array}{l}\text { Yes, well } \\
\text { managed }\end{array}$ & $\begin{array}{l}18 \\
(64.3 \%)\end{array}$ & $82(73.2 \%)$ & 0.483 \\
\hline & No, scattered & $\begin{array}{l}10 \\
(35.7 \%)\end{array}$ & $30(26.8 \%)$ & \\
\hline \multirow[t]{2}{*}{ Road conditions } & Dry & $\begin{array}{l}17 \\
(60.7 \%)\end{array}$ & $58(51.8 \%)$ & 0.525 \\
\hline & Watery & $\begin{array}{l}10 \\
(39.3 \%)\end{array}$ & $54(48.2 \%)$ & \\
\hline
\end{tabular}

\section{Result of Multivariate Analysis}

Based on the results of bivariate analysis, aspects of education, practice of prevention, house density, livestock ownership, and the distance from the house to the cowshed, and the presence of rats in the house have significant relationship with the incidence of leptospirosis. Furthermore, multivariate analysis of these variables was carried out using multiple logistic regression tests in analyzing the dominant aspect and the magnitude of risk (OR) described in Table 4.
Table 4

Results of multiple logistic regression in analyzing leptospirosis risk factors.

\begin{tabular}{llllll}
\hline Independent Variable & B & P & OR & \multicolumn{2}{c}{$95 \%$ CI for OR } \\
\cline { 5 - 6 } & & & & Lower & Upper \\
\hline Education (Low) & 1.463 & 0.019 & 4.319 & 1.278 & 14.594 \\
House density (Crowded) & 1.300 & 0.008 & 3.671 & 1.398 & 9.638 \\
Livestock ownership (Yes) & 2.627 & 0.014 & 13.830 & 1.702 & 112.382 \\
$\begin{array}{l}\text { Distance from house to } \\
\quad \text { cowshed (Less than 10 m) }\end{array}$ & 1.146 & 0.019 & 3.146 & 1.206 & 8.210 \\
$\quad$ Constant & -5.836 & 0.000 & & & \\
\hline
\end{tabular}

Based on the results of the multivariate analysis in Table 4, it is known that livestock ownership was the dominant aspect associated with the incidence of leptospirosis, followed by education, house density, and distance from house to cowshed. Livestock ownership had OR 13.830 (with 95\% CI of 1.702-112.382), means that respondents with livestock ownership had a 13.830 times greater risk of developing leptospirosis compared to respondents with no livestock ownership. Education had an OR value of 4.319 (with 95\% CI of 1.278-14.594), means that respondents with low education were at risk of developing leptospirosis 4.329 times than respondents with higher education. Furthermore, house density had an OR of 3.671 (with 95\% CI of 1.398-9.638). This means that respondents lived in a crowded house were at risk of leptospirosis 3.671 greater than those lived in uncrowded house, while the distance from house to cowshed had OR 3.146 (with $95 \%$ CI of 1.206-8.210), means that respondents who had house close to the cowshed had a 3.146 times greater risk of developing leptospirosis compared to respondents who had a house far from the cowshed.

This result shows that environmental factors and education have main role in the transmission of leptospirosis. House and environmental sanitation should receive more attention in efforts to prevent and control leptospirosis. Community behavior, especially practice of prevention, must be improved so that efforts to control leptospirosis can provide the expected results.

\section{Discussion}

Based on the results of the study, the most of leptospirosis cases were 41-60 years old and male. This is in line with the results of research conducted in Brazil which stated that leptospirosis sufferers were found in the adult male group (over 35 years) which was as much as $80 \%{ }^{26}$ This result occurred because most of the male population in the age group of 40 years work as farmers and cattle breeders as well as sand miners in rivers. This is evidenced by the results of this study that most of the sufferers also work as farmers or breeders. In addition, the results of this study are in line with research conducted by Pramestuti et al., in 2015 which stated that most leptospirosis attack men of productive age who work outside the home. ${ }^{27}$ The high risk of farmers getting leptospirosis occurs because the animals or mammals called reservoirs that appear healthy but are actually infected and can transmit leptospirosis to humans. ${ }^{28}$ Reservoirs that are in contact with the community can increase the risk of leptospirosis transmissions. Direct or indirect contact between farmers or breeders and reservoirs can be the reason for the spread of leptospirosis transmissions. ${ }^{29,30}$

Furthermore, based on the level of education, most people with leptospirosis have low level of education. The results of statistical tests also showed that respondents with a low level of education had a 4.319 times greater risk of developing leptospirosis than respondents with a high level of education. The low level of education is related to the level of knowledge about leptospirosis. ${ }^{31}$ The low level of knowledge and education about the dangers of leptospirosis can lead to a decrease in the level of awareness about leptospirosis, so that leptospirosis can easily spread among the community. ${ }^{32}$

Human behavior factors are aspects that determine human activity. Based on the results of the study in Table 2, it is known that the majority 
of leptospirosis sufferers have a lower level of knowledge, and poor practice of leptospirosis prevention. A low level of knowledge can cause a low level of public awareness of leptospirosis. Based on Table 2, it is known that leptospirosis prevention practice is associated with the incidence of leptospirosis. The results of this study mean that the incidence of leptospirosis is closely related to community behavior, especially efforts to prevent disease, especially leptospirosis. The level of education can affect the incidence of leptospirosis; people who have high level of education have an effect on disease prevention behavior which is also high by applying the importance of clean and healthy living behavior in daily life. Practices of leptospirosis prevention behavior that can be carried out include maintaining individual hygiene after activities outside the home, especially in areas or activities with a high risk of exposure to leptospirosis such as breeders and farmers. ${ }^{33}$ In addition, using personal protective equipment is also recommended for people who directly contact with livestock that can be a reservoir of

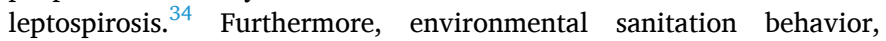
namely maintaining the cleanliness of the house environment is also very important to do because leptospirosis is not only transmitted by livestock, but can also be transmitted by rats. ${ }^{35}$

Environmental factors are one of the main factors that cause the spread of leptospirosis transmission. The house component is one of the environmental factors related to the spread of leptospirosis. House components that do not meet the requirements can lead to the presence of disease-carrying vectors, namely rats. ${ }^{36}$ House density is one aspect associated with the incidence of leptospirosis. House density is defined as the floor area in the house compared to the number of residents in the house. Based on Regulation of the Minister of Health of the Republic of Indonesia Number 829 of 1999 concerning Housing Health Requirements, the standard for house density is the unit of square meters per person under 8 square meters per person. Based on the results of the study, respondents with high housing density (crowded) had a 3.671 times greater risk of developing leptospirosis than respondents with low house density. The majority of leptospirosis sufferers in Ponorogo Regency live with a large number of family members in one house. A narrow house with a large number of residents will cause many diseases, especially infectious diseases that will easily spread to all members of the house such as leptospirosis.

Community ownership of livestock is also a source of disease transmission. Based on the multivariate logistic regression test, it yielded information that respondents who own livestock were at risk of contracting leptospirosis 13,830 times than respondents who did not own livestock (Table 4). Leptospirosis can be transmitted through livestock or mammals such as cattle or goats. This is caused by infection with pathogenic bacteria directly through the urine of infected animals or indirectly due to contact between humans and water or soil that has been contaminated with urine from infected animals. ${ }^{37}$ The results of this study were in line with the research which stated that the most of leptospirosis cases occurred in areas with ownership of pets and livestock such as dogs, buffalo, and cows. ${ }^{38}$ Also, Noach and Noach in their research found that the prevalence of leptospirosis in cattle was $20 \%$. Furthermore, the area where people live with livestock tend to be close to the cage, with the reason that they can monitor their livestock. ${ }^{39}$ The distance between the cowshed and house that are close (less than $10 \mathrm{~m}$ ) can increase the risk of leptospirosis transmission by 3146 times. This is because infected livestock do not always show symptoms. Infected livestock manure will pollute the environment around the house such as sewerages, clean water sources, and vegetation.

Furthermore, puddles of water, sewerage, and waste management are also factors associated with disease transmission, one of which is leptospirosis. But, based on the results of this study, puddles of water, sewerage, and trash can were not related to the incidence of leptospirosis in highlands of Ponorogo Regency. This happens because based on the results of interview and observations, the aspects of environmental conditions of cases and controls were the same. This finding differs from the research result of Cahyati \& Kumalasari ${ }^{40}$ that garbage storage and the existence of puddy fileds and sewerage were risk factors of leptospirosis. Their research was conducted in lowlands. Other environmental factor associated with the incidence of leptospirosis in this study was the presence of rats in the house. Most of the respondents stated that in their house, especially in leptospirosis cases, rats were found. This can be the reason for the spread of leptospirosis that can occur in some people in Ponorogo Regency. Rats as the main reservoir of leptospirosis can transmit leptospirosis bacteria directly to humans through rat droppings, or through rat tracks in trash cans, sewerages, puddles, and vegetation.

Different from several studies that have been carried out, which mostly take one aspect or factor to be analyzed, this study comprehensively analyzed individual characteristics, behavior, and environmental factors to identify risk factors for leptospirosis in highland areas. Likewise, the selection of locations in rural areas in the highlands is related to geographical conditions and the risk factors studied do not change quickly or relatively stable. However, several variables that are theoretically associated with the occurrence of leptospirosis have not been analyzed in this study, such as the type of house building, permanent or semi-permanent, floor material, and climate.

In the future, in addition to examining variables that have not been studied in this study, it is recommended to conduct further research by conducting laboratory examinations of the urine of livestock (cow or goat) or the kidneys of rats to find the presence of leptospirosis bacteria.

\section{Conclusion}

Sociodemographic factors, namely the level of education and occupation, behavioral factor, namely practice of leptospirosis prevention, and environmental factors, namely house density, livestock ownership, distance from house to cowshed and the presence of rats in the house are associated with the incidence of leptospirosis in highlands of Ponorogo Regency.

\section{Acknowledgements}

Authors would like to acknowledge the heads of Health Office and Primary Health Centers of 4 subdistricts in the highlands of Ponorogo Regency for providing secondary data on Leptospirosis.

\section{References}

1 Schneider MC, Jancloes M, Buss DF, et al. Leptospirosis: A Silent Epidemic Disease. 2013.

2 Chin J. Control of Communicable Diseases Manual. seventeenth ed. Washington: American Public Health Association; 2000.

3 Ristiyanto R, Wibawa T, Budiharta S, Supargiono S. Prevalence of rats infected with leptospira interrogans. Vektora: Jurnal Vektor dan Reservoir Penyakit. 2015 Oct 10;7 (2):85-92.

4 Wynwood SJ, Graham GC, Weier SL, Collet TA, McKay DB, Craig SB. Leptospirosis from water sources. Pathog Glob Health. 2014 Oct 1;108(7):334-338.

5 Plowright RK, Parrish CR, McCallum H, et al. Pathways to zoonotic spillover. Nat Rev Microbiol. 2017 Aug;15(8):502-510.

6 Costa F, Martinez-Silveira MS, Hagan JE, Hartskeerl RA, Reis MG, Ko AI. Surveillance for leptospirosis in the Americas, 1996-2005: a review of data from ministries of health. Rev Panam Salud Públic. 2012;32:169-177.

7 Marami LM, Gebremedhin EZ, Sarba EJ, et al. Seroprevalence and associated risk factors of canine leptospira and Brucella species infection in west shewa zone, Central Ethiopia. Vet Med Res Rep. 2021;12:33.

8 Marami LM, Gebremedhin EZ, Sarba EJ, et al. Seroprevalence and associated risk factors of canine leptospira and Brucella species infection in west shewa zone, Central Ethiopia. Vet Med Res Rep. 2021;12:33.

9 Zakharova OI, Korennoy FI, Toropova NN, Burova OA, Blokhin AA. Environmental risk of leptospirosis in animals: the case of the republic of sakha (yakutia), Russian federation. Pathogens. 2020 Jun;9(6):504.

10 Barcellos C, Sabroza PC. The place behind the case: leptospirosis risks and associated environmental conditions in a flood-related outbreak in Rio de Janeiro. Cad Saúde Pública. 2001;17:S59-S67.

11 Susanna D, Nova RI, Rozek L. The existence and characteristics of rats and shrews in endemic leptospirosis areas and types of ectoparasites: a case study of West Jakarta, Indonesia. Res. 2021 Apr 30;10(335):335.

12 Ministry of Health of the Republic of Indonesia. Indonesia Health Profile 2015. 2016. Jakarta. 
13 Mirasa YA, Yudhastuti R, Wahyuni CU, Adi MS. Study of risk factor and epidemiology surveillance system of leptospirosis. Damage. Int. J. Res. 2017;2(7): $12-23$.

14 Zakharova OI, Korennoy FI, Iashin IV, et al. Ecological and socio-economic determinants of livestock animal leptospirosis in the Russian arctic. Front. Vet. Sci. 2021 Apr 12;8:323.

15 Asaaga FA, Young JC, Oommen MA, et al. Operationalising the "One Health" approach in India: facilitators of and barriers to effective cross-sector convergence for zoonoses prevention and control. BMC Publ Health. 2021 Dec;21(1):1-21.

16 Haake DA, Levett PN. Leptospirosis in Humans. Leptospira and leptospirosis; 2015: 65-97.

17 Felzemburgh RD, Ribeiro GS, Costa F, et al. Prospective study of leptospirosis transmission in an urban slum community: role of poor environment in repeated exposures to the Leptospira agent. PLoS Neglected Trop Dis. 2014 May 29;8(5):e2927.

18 Directorate General of P2PL Ministry of Health RI. Technical Instructions of Leptospirosis Control. 2014. Jakarta.

19 Ponorogo Health Office. Ponorogo District Health Profile 2015. Ponorogo; 2015.

20 Sohail ML, Khan MS, Ijaz M, et al. Seroprevalence and risk factor analysis of human leptospirosis in distinct climatic regions of Pakistan. Acta Trop. 2018 May 1;181: 79-83.

21 Kamath R, Swain S, Pattanshetty S, Nair NS. Studying risk factors associated with human leptospirosis. J Global Infect Dis. 2014 Jan;6(1):3.

22 Hinjoy S, Kongyu S, Doung-Ngern P, et al. Environmental and behavioral risk factors for severe leptospirosis in Thailand. Trop. Med. Infect. Dis. 2019 Jun;4(2):79.

23 Trimawan HW, Tuhu P, Rusmiati. Study of Factors Influencing the Incidence of Leptospirosis in Ponorogo. Surabaya Polytechnic; 2014.

24 Mwachui MA, Crump L, Hartskeerl R, Zinsstag J, Hattendorf J. Environmental and behavioural determinants of leptospirosis transmission: a systematic review. PLOS Neglected Trop Dis. 2015 Sep 17;9(9), e0003843.

25 Hartskeerl RA, Collares-Pereira M, Ellis WA. Emergence, control and re-emerging leptospirosis: dynamics of infection in the changing world. Clin. Microbiol. Infect. 2011 Apr 1;17(4):494-501.

26 Tsay AJ. reportLeptospirosis Pulmonary Hemorrhage Syndrome in Salvador, Brazil from 2003-2012 (Doctoral Dissertation, Yale University).

27 Pramestuti N, Djati AP, Kesuma AP. Risk factors of leptospirosis outbreak after flood in pati district 2014. Vektora. 2015;7(1):1-6.
28 Marbawati D, Harilsmanto H, Pramestuti N. Characteristic of rats as reservoirs of leptospirosis. Kes. Mass: Jurnal Fakultas Kesehatan Masyarakat Universitas Ahmad Daulan. 2016;10(1):69-74.

29 Lau CL, Smythe LD, Craig SB, Weinstein P. Climate change, flooding, urbanisation and leptospirosis: fuelling the fire? Trans R Soc Trop Med Hyg. 2010 Oct 1;104(10): 631-638.

30 Putz EJ, Nally JE. Investigating the immunological and biological equilibrium of reservoir hosts and pathogenic leptospira: balancing the solution to an acute problem? Front Microbiol. 2020 Aug 14;11:2005.

31 Dewi M, Wawan A. Theory and Measurement of Knowledge of Attitudes and Human Behavior. Yogyakarta: Nuha Medika; 2010.

32 Azhari NN, Abdul Manaf R, Ng SW, et al. Gamification, a successful method to foster leptospirosis knowledge among university students: a pilot study. Int $J$ Environ Res Publ Health. 2019 Jan;16(12):2108.

33 Alexander MN. The Prevalence of Leptospira Species in Fresh Water Fish in Selected Areas of Morogoro Municipality, Tanzania (Doctoral Dissertation. Sokoine University of Agriculture); 2017.

3418 Balamurugan V. Agent specific biosafety and biosecurity practices: leptospira spp. SAARC Reg. Train. 2019 Aug 19:18.

35 Azfar ZM, Nazri SM, Rusli AM, et al. Knowledge, attitude and practice about leptospirosis prevention among town service workers in northeastern Malaysia: a cross sectional study. J. Prev. Med. Hyg. 2018 Mar;59(1):E92.

36 Equator NA, Lestari KS. Analysis of house conditions and the presence of rats that affect the incidence of leptospirosis in klaten regency. J Environ Health 8(1): 12016.

37 Rees EM, Minter A, Edmunds WJ, Lau CL, Kucharski AJ, Lowe R. Transmission modelling of environmentally persistent zoonotic diseases: a systematic review. Lancet. Planet. Health. 2021 Jul 1;5(7):e466-e478.

38 Deresa B, Tulu D, Deressa FB. Epidemiological investigation of cattle abortion and its association with brucellosis in jimma zone, Ethiopia. Vet Med Res Rep. 2020;11:87.

39 Noach SM, Noach YR. Prevalence rate and causes of leptospirosis serovar on cattle at Giwangan's abattoir of Yogyakarta. J. Trop. Anim. Sci. Technol. 2020 Jul 31;2(1): $37-42$.

40 Cahyati WH, Kumalasari LD. Spatial analysis of environmental factors of leptospirosis in bonang subdistrict. Demak District 2018. Visikes. 2020;19(1): $196-211$. 